\title{
Mixed Infection of Hard Red Winter Wheat with High Plains Virus and Wheat Streak Mosaic Virus from Wheat Curl Mites in Nebraska
}

\author{
T. Mahmood, Texas Agricultural Experiment Station, Bushland 79012; G. L. Hein, University of Nebraska, Pan- \\ handle Research \& Extension Center, Scottsbluff 69361; and S. G. Jensen, Department of Plant Pathology, Univer- \\ sity of Nebraska, Lincoln 68583
}

\begin{abstract}
Mahmood, T., Hein, G. L., and Jensen, S. G. 1998. Mixed infection of hard red winter wheat with High Plains virus and wheat streak mosaic virus from wheat curl mites in Nebraska. Plant Dis. 82:311-315.

A new disease of wheat and corn caused by the High Plains virus (HPV) has been observed in the High Plains region of western United States. HPV is transmitted by the wheat curl mite, Aceria tosichella, which is also the vector of wheat streak mosaic virus (WSMV). In the field it is extremely difficult to visually differentiate plants infected with WSMV from those with HPV. An indirect protein-A sandwich enzyme-linked immunosorbent assay (PAS-ELISA) and Western blot analysis were used to identify WSMV and HPV. Samples of wheat curl mites were collected from arbitrarily chosen sites from commercial wheat plantings in 1995 and 1996 and used to infest caged wheat plants. After 3 weeks, leaf samples were harvested and assayed. Both Western blot analysis and PAS-ELISA were effective at identifying samples positive for WSMV and HPV, both alone and in mixed infections. Western blot results showed that over the 2 years, $65 \%$ of the samples were positive for WSMV, $46 \%$ were positive for HPV, and mixed infections were found in $40 \%$ of the samples. HPV presence was verified with similar results from field collected plant samples. These levels of virus indicate an unexpectedly high incidence of HPV in wheat curl mite populations in Nebraska.
\end{abstract}

A new virus called High Plains virus (HPV) has been found scattered throughout the High Plains and intermountain area from Texas to South Dakota and from $\mathrm{Ne}$ braska to Idaho. It was first identified in Nebraska in corn in 1994 (9,11). Currently, wheat, corn, and barley have been identified as crops that can be systemically infected by HPV (18). HPV has an associated $32 \mathrm{kDa}$ protein which is probably a nucleoprotein rather than capsid protein $(10,12)$.

The ultrastructure of HPV-infected cells have been described, and it resembles the ultrastructure of cells infected with roserosette, redbud yellow ringspot, fig mosaic, and thistle mosaic pathogens (1). Viroplasms and large ovoid to spherical double membrane-bound bodies 150 to $200 \mathrm{~nm}$ in diameter characterize the infected cells. HPV is not mechanically transmissible, but it has been shown to be transmitted by the wheat curl mite (WCM; 18), Aceria tosichella Keifer (2). The WCM also transmits wheat streak mosaic virus (WSMV; 19). Some plants of both wheat and corn have been found to be doubly infected

Corresponding author: Gary L. Hein

E-mail: entm008@unlvm.unl.edu

Published as Journal Series Paper No. 11875, Nebraska Agriculture Research Division.

Accepted for publication 24 November 1997.

Publication no. D-1998-0112-02R

(C) 1998 The American Phytopathological Society
$(4,8,17,18)$. Our observations indicate that the epidemiology of HPV may be similar to WSMV because of their mutual association with the WCM vector. However, the potential for field populations of WCM to transmit HPV is not known.

Symptoms of HPV on wheat are similar to WSMV, but they can be much more severe. We have observed that plants infected with HPV are mottled, chlorotic, severely stunted, and may die. The incidence of HPV infection can range from a few plants in a small area up to all of the wheat or maize plants in a large area. Growth stage at the time of infection, temperature, and host susceptibility all appear to play a role in the intensity of disease development and damage.

Under field conditions, cultivated plants may be infected with more than one pathogen. There have been no previous studies relating to the incidence of mixed infections of HPV and WSMV in commercial hard red winter wheat plantings in $\mathrm{Ne}$ braska. It is very important to determine the incidence of HPV in the field and the effectiveness with which mite populations can transmit both HPV and WSMV. The purpose of this study was to determine to what extent, if any, WCM arbitrarily collected from maturing winter wheat in $\mathrm{Ne}$ braska transmit WSMV and HPV.

\section{MATERIALS AND METHODS}

Wheat curl mite sampling for virus assay. Maturing heads of wheat (soft to hard dough stage) containing WCM were randomly collected from commercial plantings from four different locations in western Nebraska (Grant, Big Springs, Oshkosh, and Kimball) in July 1995, and from Scottsbluff, Kimball, Sidney, Crawford, and Oshkosh (panhandle Nebraska); Grant and Big Springs (southwest Nebraska); Lincoln (eastern Nebraska); and Clay Center (central Nebraska) in July 1996. At each location, five fields were sampled in 1995 and two fields in 1996. Ten heads were collected from each of ten different sites in each field in 1995, and 7 heads were collected from each of five different sites in each field in 1996. From the heads collected from each field, 5 heads from each site in 1995 (50 per field) and 2 heads from each site in 1996 (10 per field) were placed on sticky tapes (7). As the wheat heads dried, the WCM abandoned the heads and became stuck on the sticky tape. Counts of the WCM trapped on the tape were taken under a stereoscopic microscope. In 1995 and again in 1996, WCM on sticky tapes from at least 10 heads from each field were counted.

In each year, the remaining 5 wheat heads from each site within a field were placed on 6 to 8 healthy, four-leaf-stage wheat seedlings (cultivar Arapahoe) growing in a single pot. Ten pots per field ( 1 per site; 50 per location) were used in 1995 , and 5 pots per field (1 per site; 10 per location) were used in 1996. The pots were individually caged to prevent contamination. WCM were allowed to move off the heads onto the young wheat plants. As a check, healthy four-leaf wheat seedlings were grown in pots in the greenhouse. No wheat heads were added to the check pots, and they were caged and maintained beside the infested pots. Plants were maintained in the greenhouse under natural light conditions with a temperature range of 18 to $27^{\circ} \mathrm{C}$ for 3 weeks before plants were assayed for WSMV and HPV.

Virus identification. From each of the head-infested and uninfested pots maintained in the greenhouse, samples of 2 plants in 1995 (100 per location) and 4 plants in 1996 (40 per location) were collected and held at $-20^{\circ} \mathrm{C}$ for 1 to 2 months until they were assayed for mixed infection of WSMV and HPV by Western blotting and enzyme-linked immunosorbent assay (ELISA). Samples for negative controls were collected from healthy wheat uninfested with WCM. 
Western blot analysis for virus infection. Viral proteins in leaf samples were prepared by grinding leaf samples in a ratio 1:10 (wt/vol) in Tris-buffered saline (TBS; $\mathrm{pH} 7.2,0.05 \mathrm{M}$ Tris-HCl, $0.2 \mathrm{M} \mathrm{NaCl}$ ). The mixture was centrifuged at $12,000 \times g$ for $15 \mathrm{~min}$ to remove large particulates. The aqueous supernatant was mixed with sample buffer (0.125 M Tris- $\mathrm{HCl}, \mathrm{pH} 6.8$; $4 \%$ glycerol [wt/vol], 5\% 2-mercaptethonol [ $\mathrm{vol} / \mathrm{vol}]$, and $0.004 \%$ bromophenol blue) in a $1: 1$ ratio, heated at $100^{\circ} \mathrm{C}$ for 5 min, and chilled in ice water. These samples were assayed by sodium dodecyl sulfate-polyacrylamide gel electrophoresis (SDS-PAGE) on vertical mini-slab gels

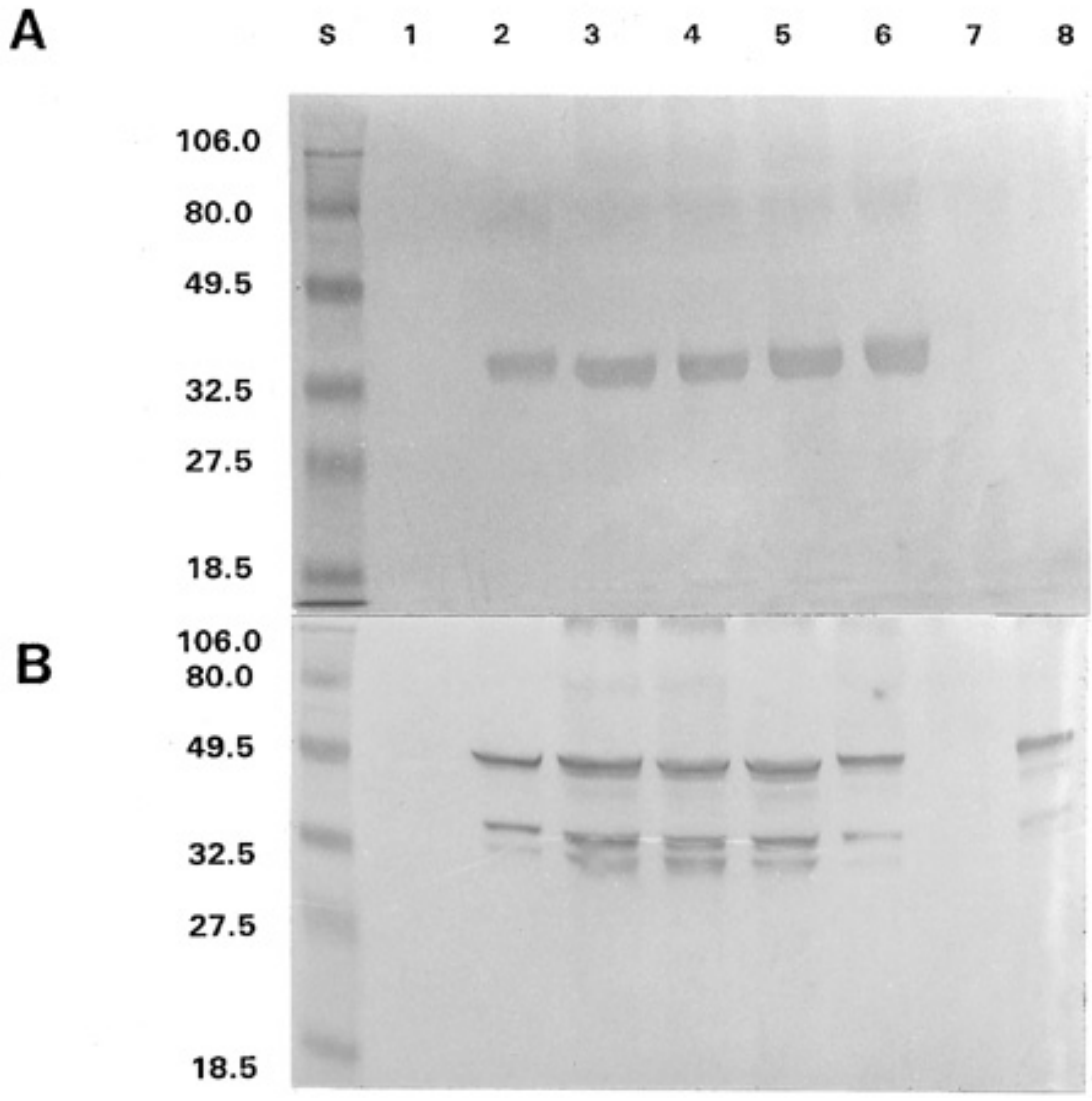

Fig. 1. Detection of (A) High Plains virus (HPV) and (B) wheat streak mosaic virus (WSMV) by Western blotting after probing with antibodies to WSMV $(1.3 \mathrm{mg} / \mathrm{ml}$ at $1: 1,000$ dilution) and HPV $(1.0 \mathrm{mg} / \mathrm{ml}$ at $1: 500$ dilution), and anti-rabbit goat antibody alkaline-phosphatase conjugate $(1: 1,000$ for WSMV and 1:500 for HPV). Lane S, molecular mass standards; lane 1, healthy wheat; lane 2, known positive control, (A) HPV-infected wheat and (B) WSMV-infected wheat; and lane 3 to 8, wheat samples collected from potted plants after wheat curl mite (WCM) transmission (unknowns). with $12 \%$ resolving gel and $5 \%$ stacking gel $(30 / 0.8 \%)$ for $45 \mathrm{~min}$ at $200 \mathrm{~V}(15)$. Prestained molecular standards (Bio-Rad Laboratories, Richmond, CA) were included on the gel for estimation of relative molecular masses. Molecular mass of viral proteins were estimated from a regression equation of the log of molecular weight of the standard proteins versus distance migrated.

After SDS-PAGE, proteins were transferred electrophoretically onto the separate nitrocellulose membrane ( 0.45 microns; Bio-Rad Laboratories) by the method of Towbin et al. (20) for $20 \mathrm{~min}$ at $15 \mathrm{~V}$ using a semidry transblotter as recommended by the manufacturer (Bio-Rad Laboratories). After the membranes were blocked overnight at $4^{\circ} \mathrm{C}$ with $5 \%$ nonfat dry milk in TBS, they were incubated for $2 \mathrm{~h}$ in antiviral antibodies $(1 \mu \mathrm{g} / \mathrm{ml}$ for WSMV and 2 $\mu \mathrm{g} / \mathrm{ml}$ for HPV). The anti-WSMV rabbit immunoglobulin $\mathrm{G}$ was prepared against the Sidney isolate of WSMV (3) and was supplied by R. C. Gergerich, University of Arkansas. The antiserum for HPV was prepared against $32 \mathrm{kDa}$ nucleoprotein purified from density gradient purification of HPV (12). For WSMV, the membranes were washed three times for $10 \mathrm{~min}$ in TBS, followed by an incubation for $2 \mathrm{~h}$ in a $1: 1,000 \mathrm{vol} / \mathrm{vol}(0.8 \mathrm{mg} / \mathrm{ml})$ solution of goat anti-rabbit antibody conjugated to alkaline-phosphatase (Sigma Chemical Co., St. Louis). For HPV, incubation was for $2 \mathrm{~h}$ in a $1: 500 \mathrm{vol} / \mathrm{vol}(0.8 \mathrm{mg} / \mathrm{ml})$ solution of goat anti-rabbit antibody conjugated to alkaline-phosphatase (Sigma Chemical Co.). After washing with TBS, the presence of alkaline phosphatase was demonstrated by reacting the membranes with bromochloroindolyl phosphate/nitro blue tetrazolium substrate.

Detection of WSMV and HPV by ELISA. An indirect protein-A sandwich enzyme-linked immunosorbent assay (PASELISA; 5) was used to assay separately for

Table 1. Detection of wheat streak mosaic virus (WSMV) and High Plains virus (HPV) by Western blotting from hard red winter wheat collected from Nebraska during 1995 and 1996

\begin{tabular}{|c|c|c|c|c|c|}
\hline \multirow[b]{2}{*}{ Year $^{\mathbf{a}}$} & \multirow[b]{2}{*}{ Collection location } & \multirow[b]{2}{*}{ Number of samples } & \multicolumn{3}{|c|}{ Number of samples positive } \\
\hline & & & WSMV & HPV & Mixed infection \\
\hline \multirow[t]{4}{*}{1995} & Grant & 100 & 69 & 57 & 51 \\
\hline & Oshkosh & 100 & 69 & 29 & 26 \\
\hline & Big Springs & 100 & 89 & 61 & 59 \\
\hline & Kimball & 100 & 66 & 53 & 39 \\
\hline Total & & 400 & $293(73 \%)$ & $200(50 \%)$ & $175(44 \%)$ \\
\hline \multirow[t]{9}{*}{1996} & Crawford & 40 & 26 & 9 & 9 \\
\hline & Scottsbluff & 40 & 14 & 14 & 8 \\
\hline & Kimball & 40 & 31 & 25 & 20 \\
\hline & Sidney & 40 & 14 & 6 & 6 \\
\hline & Oshkosh & 40 & 38 & 35 & 33 \\
\hline & Big Springs & 40 & 31 & 25 & 25 \\
\hline & Grant & 40 & 26 & 22 & 21 \\
\hline & Lincoln & 40 & 7 & 1 & 0 \\
\hline & Clay Center ${ }^{b}$ & 20 & 0 & 2 & 0 \\
\hline Total & & 340 & $187(55 \%)$ & $139(41 \%)$ & $122(36 \%)$ \\
\hline
\end{tabular}

\footnotetext{
a Samples were collected during July 1995 and 1996.
}

${ }^{\mathrm{b}}$ Samples were collected from one field. 
WSMV and HPV. Positive controls for WSMV and HPV were known infected wheat tissue, and negative controls were extracts from healthy wheat. Samples were prepared by extracting approximately $0.2 \mathrm{~g}$ frozen tissue in $2 \mathrm{ml}$ extraction buffer (phosphate-buffered saline plus $0.05 \%$ Tween 20) with a leaf presser (Ravenel Specialties Co., Seneca, SC).

Microtiter plates were coated with 1 $\mu \mathrm{g} / \mathrm{ml}$ protein A (Sigma Chemical Co.) followed by virus-specific antiserum. Antiserum to WSMV $(1.3 \mathrm{mg} / \mathrm{ml})$ was used at a dilution of $1 \mu \mathrm{g} / \mathrm{ml}$, whereas antiserum to HPV $(1.0 \mathrm{mg} / \mathrm{ml})$ was used at a dilution of $2 \mu \mathrm{g} / \mathrm{ml}$. Sap extracts from plants were incubated in ELISA plate wells overnight at $4^{\circ} \mathrm{C}$. All other incubation steps were at room temperature for $2 \mathrm{~h}$. A specific WSMV antiserum $(1.3 \mathrm{mg} / \mathrm{ml})$ at a dilution of $1 \mu \mathrm{g} / \mathrm{ml}$ and HPV antiserum $(1.0 \mathrm{mg} / \mathrm{ml})$ at a dilution of $2 \mu \mathrm{g} / \mathrm{ml}$ was used as a second antibody. After incubation and washing, protein A conjugated to alkaline phosphatase (Sigma Chemical Co.) was used at a concentration of $1 \mu \mathrm{g} / \mathrm{ml}$. The substrate was $p$-nitrophenyl phosphate $(1 \mathrm{mg} / \mathrm{ml})$. Each plate contained noninfected controls (four wells per plate), infected controls (four wells per plate) and 40 to 44 samples (two wells per sample).

Quantitative measurements of the alkaline phosphatase reactions were made by determining absorbance at $405 \mathrm{~nm}$ with an MR 4000 Micro ELISA plate reader (Dynatech Laboratories, Chantilly, VA). Plants were considered positive for the virus when the mean $A_{405}$ of the replicate samples was greater than three times the mean absorbance of negative controls in the same plate. Effectiveness of ELISA test runs were always verified with the use of positive controls.

Leaf sampling for virus assay. Wheat leaf samples were collected from commercial plantings near Kimball, Sidney, Osh- kosh, Grant, and Big Springs during June 1996. To estimate the incidence of mixed infection, 3 to 4 leaves from each of 88 plants were collected randomly from each location following a grid pattern with a 9$\mathrm{m}$ spacing in an $80-$ by $100-\mathrm{m}$ block. Samples were collected without regard to symptoms, and plants were in the early heading stages (late boot through anthesis). Samples were frozen at $-20^{\circ} \mathrm{C}$ for 2 months, then assayed by PAS-ELISA for WSMV and HPV (5).

\section{RESULTS}

Leaf symptoms. In the greenhouse, plants developed symptoms within 10 to 14 days after the heads from the field were placed on young potted wheat plants. Leaf symptoms, such as a yellow mosaic pattern of parallel discontinuous streaks and leaf mottling, were very similar to those caused by WSMV. In many cases, leaf symptoms were more severe than the symptoms of WSMV alone. In these cases, the leaves had more chlorotic striping and mottling and showed more necrosis of the older leaves.

Western blot analysis for WCM transmission. Western blot analysis showed that the samples positive for WSMV contained the WSMV capsid protein of approximately $44 \mathrm{kDa}$ (Fig. 1B). In many sample preparations, 34 and $31 \mathrm{kDa}$ proteins were also detected. These were the degradation products of the capsid protein of WSMV (3). Preparations from the HPVpositive leaves contained a protein of approximately $33 \mathrm{kDa}$ (Fig. 1A). Occasionally, a less intense protein band developed on the nitrocellulose membranes at the position of $80 \mathrm{kDa}$, but sometimes this band was also present in the samples which were prepared from healthy wheat (data not shown). These were probably caused by the presence of low levels of antibodies to healthy plant components in the HPV antiserum. This $80 \mathrm{kDa}$ band was also present in samples in which $33 \mathrm{kDa}$ protein was not revealed. HPV antiserum did not cross-react with WSMV.

In 1995 and 1996, WSMV was commonly detected from all locations except for the Clay Center location in south-central Nebraska (Table 1). Of all samples tested, 293 of $400(73 \%)$ were identified as positive for WSMV in 1995, and 187 of $340(55 \%)$ were positive in 1996. HPV was detected in 200 of 400 samples $(50 \%)$ in 1995 and 139 of 340 (41\%) in 1996. Double infections were found in 175 of 400 samples (44\%) in 1995 and 122 of 340 samples $(36 \%)$ in 1996. Virus infection was most common in WCM collected from the panhandle and southwest Nebraska. The viruses had a much lower incidence in samples collected from eastern and central Nebraska. Uninfested controls all tested negative for both WSMV and HPV, indicating there was no cross contamination of WCM between caged pots.

PAS-ELISA detection of viruses. When the same samples were tested by PAS-ELISA, double infections of WSMV and HPV were identified in all locations in 1995 (Table 2). Of 400 samples tested, 208 (52\%) were found positive for WSMV, and HPV was identified in 145 (36\%) samples. Double infection was detected in 111 (28\%) samples. WSMV, HPV, and mixed infections were all most prevalent in Big Springs. In 1996, 148 of 340 samples (44\%) were positive for WSMV, and 101 $(30 \%)$ were positive for HPV. Mixed infections were found in 77 samples $(23 \%)$. Mixed infections were identified from all locations except eastern (Lincoln) and central (Clay Center) Nebraska, where the incidence of WSMV and HPV were both low.

For all the samples tested over the 2 years, $98 \%$ of the samples that tested positive by PAS-ELISA also tested positive by

Table 2. Detection of wheat streak mosaic virus (WSMV) and High Plains virus (HPV) by PAS-ELISA ${ }^{\text {a }}$ from hard red winter wheat collected from Nebraska during 1995 and 1996

\begin{tabular}{|c|c|c|c|c|c|}
\hline \multirow[b]{2}{*}{ Year $^{\mathbf{b}}$} & \multirow[b]{2}{*}{ Collection location } & \multirow[b]{2}{*}{ Number of samples } & \multicolumn{3}{|c|}{ Number of samples positive } \\
\hline & & & WSMV & HPV & Mixed infection \\
\hline \multirow[t]{4}{*}{1995} & Grant & 100 & 51 & 33 & 25 \\
\hline & Oshkosh & 100 & 44 & 28 & 18 \\
\hline & Big Springs & 100 & 80 & 59 & 48 \\
\hline & Kimball & 100 & 33 & 25 & 20 \\
\hline Total & & 400 & $208(52 \%)$ & $145(36 \%)$ & $111(28 \%)$ \\
\hline \multirow[t]{9}{*}{1996} & Crawford & 40 & 24 & 8 & 7 \\
\hline & Scottsbluff & 40 & 10 & 20 & 9 \\
\hline & Kimball & 40 & 29 & 15 & 15 \\
\hline & Sidney & 40 & 11 & 6 & 2 \\
\hline & Oshkosh & 40 & 29 & 13 & 13 \\
\hline & Big Springs & 40 & 15 & 16 & 14 \\
\hline & Grant & 40 & 24 & 20 & 17 \\
\hline & Lincoln & 40 & 6 & 1 & 0 \\
\hline & Clay Center ${ }^{c}$ & 20 & 0 & 2 & 0 \\
\hline Total & & 340 & $148(44 \%)$ & $101(30 \%)$ & $77(23 \%)$ \\
\hline
\end{tabular}

${ }^{\text {a }}$ Protein-A sandwich enzyme-linked immunosorbent assay.

b Samples were collected during July 1995 and 1996.

${ }^{\mathrm{c}}$ Samples were collected from one field only. 
Western blot analysis. Conversely, PASELISA detected positive WSMV, HPV, and mixed infections 74,73 , and $63 \%$ of the time, respectively, when compared to Western blotting.

The presence of WSMV and HPV in 1996 detected by PAS-ELISA from fieldcollected wheat is shown in Table 3 . WSMV and HPV were detected in samples collected from all locations, but WSMV was about three times more prevalent. Of the 440 samples tested, $181(41 \%)$ were positive for WSMV, 57 (13\%) were positive for HPV, and $40(9 \%)$ were positive for both. The ratio of samples positive for WSMV to those positive for HPV for these field collected wheat samples was about $3: 1$, which is substantially higher than the ratio for the greenhouse samples (1.4:1) summarized in Table 2.

Wheat curl mites. The number of WCM per head varied greatly across fields and locations in both years (Table 4). In 1995, WCM numbers for the 20 fields sampled ranged from 22 to 2,958 mites per head; for the 17 fields sampled in 1996, the range was from 3 to 1,838 mites per head. Correlations between average WCM per head for each field and virus presence in that field were significant $(P<0.01, n=37$ fields) for both viruses and both assay procedures. For Western blot, these correlations were 0.48 and 0.46 for WSMV and
HPV, respectively. Slightly higher correlations were obtained for the ELISA results: 0.68 and 0.52 for WSMV and HPV, respectively. This indicates that the locations showing the highest virus incidence also had relatively high WCM numbers.

\section{DISCUSSION}

In this study, mixed infection of winter wheat by WSMV and HPV was identified by both PAS-ELISA and Western blotting. Although both assays worked well for the detection of WSMV and HPV, Western blotting was the most sensitive in detecting both viruses. The 2 years during which this study was conducted were characterized by a low incidence of serious wheat streak mosaic infections in the field in Nebraska. However, both viruses were transmitted by WCM populations which were present in large numbers on commercial wheat plantings in Nebraska (Table 4). These findings lead us to believe that the newly identified HPV is widespread in wheat in Nebraska and is readily transmitted by WCM populations. Also, it appears that the epidemiology of HPV will be similar to WSMV because they are both vectored by WCM. Greenhouse test plants developed severe virus disease symptoms when infested with WCM from Big Springs, Oshkosh, Kimball, and Grant, indicating that virus was abundant at these locations.

Table 3. Detection of wheat streak mosaic virus (WSMV) and High Plains virus (HPV) by PASELISA $^{\mathrm{a}}$ from field-collected hard red winter wheat leaf samples collected arbitrarily without regard for symptoms from western Nebraska during 1996

\begin{tabular}{lcccc}
\hline & & \multicolumn{3}{c}{ Number of samples positive } \\
\cline { 3 - 5 } Collection location & Number of samples & WSMV & HPV & Mixed infections \\
\hline Kimball & 88 & 11 & 6 & 2 \\
Oshkosh & 88 & 33 & 6 & 5 \\
Grant & 88 & 51 & 14 & 11 \\
Big Springs & 88 & 41 & 29 & 20 \\
Sidney & 88 & 45 & 2 & 2 \\
Total & 440 & $181(41 \%)$ & $57(13 \%)$ & $40(9 \%)$ \\
\hline
\end{tabular}

a Protein-A sandwich enzyme linked immunosorbent assay.

${ }^{\mathrm{b}}$ Samples were collected when plants were in the soft dough stage.

The high proportion of mixed infections indicates that both viruses can be effectively transmitted by WCM populations. If transmission of the two viruses were independent, the probability of getting mixed infections should be the product of the probability of occurrence of each virus. Using the 1995 and 1996 data from the Western blot analyses (Table 1), the probability of a positive WSMV test was 0.65 (480 out of 740), and the probability of a positive HPV test was 0.46 (339 out of 740). From these probabilities, the expected probability of a mixed infection should be 0.30 . However, the observed probability was 0.40 (297 out of 740). Chisquare analysis of these data indicate that the observed probability of a mixed infection was significantly greater than the expected $\left(\chi^{2}=38.35, P>\chi^{2}<0.01\right)$. Therefore, transmission of the two viruses by mite populations may not be totally independent. However, it is apparent from our data that transmission of only a single virus is common. Further understanding of the transmission of HPV and its relationship with WSMV transmission is needed.

The prevalence of HPV in WCM populations raises the question of how long this disease has been in Nebraska. A severe WSMV epiphytotic in 1993 in western Nebraska contained many unusual observations not normally associated with WSMV epiphytotics. For example, fields were showing serious disease symptoms in the fall, which is unusual for WSMV. The findings in this study showing a widespread presence of HPV indicate that HPV was likely present, and the severe losses in 1993 may have resulted from HPV or a mixed infection of WSMV and HPV.

The $33 \mathrm{kDa}$ nucleoprotein of HPV detected by Western blotting was about the same size as one of the degradation products of the coat protein of WSMV. In Western blots, samples known to be positive for HPV reacted only to antiserum made to HPV; they did not react to antiserum to WSMV, and vice versa. This indi-

Table 4. Average numbers of wheat curl mites (WCM) from hard red winter wheat heads collected from four different locations in western Nebraska during summer 1995 and from nine different locations in Nebraska during summer 1996

\begin{tabular}{|c|c|c|c|c|c|c|c|}
\hline \multirow[b]{2}{*}{ Year $^{\mathbf{a}}$} & \multirow[b]{2}{*}{ Collection location } & \multicolumn{6}{|c|}{ WCM per head $^{\mathrm{b}}$} \\
\hline & & 1 & 2 & 3 & 4 & 5 & Mean \\
\hline \multirow[t]{4}{*}{1995} & Grant & 696 & 343 & 584 & 2,958 & 913 & 1,099 \\
\hline & Oshkosh & 843 & 659 & 300 & 1,311 & 82 & 639 \\
\hline & Big Springs & 2,213 & 2,339 & 2,604 & 893 & 1,310 & 1,872 \\
\hline & Kimball & 153 & 71 & 300 & 22 & 348 & 179 \\
\hline \multirow{9}{*}{1996} & Crawford & 59 & 1,768 & & & & 914 \\
\hline & Scottsbluff & 216 & 120 & & & & 168 \\
\hline & Kimball & 229 & 1,117 & & & & 673 \\
\hline & Sidney & 3 & 43 & & & & 23 \\
\hline & Oshkosh & 592 & 1,838 & & & & 1,215 \\
\hline & Big Springs & 557 & 401 & & & & 479 \\
\hline & Grant & 702 & 211 & & & & 456 \\
\hline & Lincoln & 107 & 65 & & & & 86 \\
\hline & Clay Center & 267 & $\ldots$ & & & & 267 \\
\hline
\end{tabular}

\footnotetext{
a Samples were collected during July 1995 and 1996.
}

b At each location, samples were collected from five fields in 1995 and two fields in 1996. Values are averages of a minimum of 10 heads from each field. 
cates that the HPV protein is not a modified form of WSMV protein, nor would it be confused with WSMV proteins in these tests. Moreover, in PAS-ELISA, there were samples that reacted positively for WSMV and reacted negatively for HPV. This demonstrates the ability of these tests to accurately discriminate between the two viruses in single and mixed infections.

There have been numerous reports of mixed infection of two viruses $(6,13,16)$. In some cases, mixed infections lead to synergistic interaction (14). Our field observations and limited greenhouse data (S. Jensen, unpublished data) indicate this may be the case with WSMV and HPV in wheat. The presence of both HPV and WSMV in wheat leads to severe chlorosis, stunting, and necrosis, which may result in severe yield reductions. Since WSMV is mechanically transmitted, it is relatively easy to study the effects of this virus alone. However, HPV is obligately vectored by the WCM, and it is difficult to work with HPV alone since mite colonies in culture, or populations from the field, normally carry both viruses. Further studies will be required to determine if there is synergism occurring between these two viruses, or if HPV alone can produce the severe effect observed in the field. Our results show that, under field conditions in western $\mathrm{Ne}$ braska, WCM populations typically transmit both viruses, and wheat plants are commonly infected with both HPV and WSMV.

Serious economic field infections of WSMV and HPV were rare in Nebraska in both 1995 and 1996. This work demonstrates that even in these non-epidemic years, the level at which WCM populations transmit both viruses across the entire state remains high.

\section{ACKNOWLEDGMENTS}

We thank Roy French and Robert Wright for providing wheat samples in 1996; and John Watkins, Roy French, and John Foster for reviewing earlier drafts of the manuscript.

\section{LITERATURE CITED}

1. Ahn, K. K., Kim, K. S., Gergerich, R. C., Jensen, S. G., and Anderson, E. J. 1996. Comparative ultrastructure of double membrane-bound particles and inclusions associated with eriophyid mite-borne plant diseases of unknown etiology: a potentially new group of plant viruses. J. of Submicrosc. Cyto. Pathol. 28:345-355.

2. Amrine, J. W. Jr., and Stasny, T. A. 1994. Catalog of Eriophyoidea (Acarina:Prostigmata) of the world. Indira Publishing Co., W. Bloomfield, MI.

3. Brakke, M. K., Skopp, R. N., and Lane, L. C. 1990. Degradation of wheat streak mosaic virus capsid protein during leaf senescence. Phytopathology 80:1401-1405.

4. Brown, W. M. Jr., French, R. C., Hammond, R. W., and Jensen, S. G. 1994. Occurrence and distribution of wheat viruses in Colorado. Phytopathology 84:1167.

5. Edwards, M. L., and Cooper, J. I. 1985. Plant virus detection using a new form of indirect ELISA. J. Virol. Methods 11:309-319.

6. Hamilton, R. I., and Nichols, C. 1977. The influence of bromegrass mosaic virus on the replication of tobacco mosaic virus in Hordeum vulgare. Phytopathology 67:484-489.

7. Harvey, T. L., and Martin, T. J. 1988. Stickytape method to measure cultivar effect on wheat curl mite (Aceria: Eriophyidae) populations in wheat spikes. J. Econ. Entomol. $1: 731-734$

8. Jardine, D. J., Bowden, R. L., and Jensen, S. G. 1994. A new virus of corn and wheat in western Kansas. Phytopathology 84:11171118.
9. Jensen, S. G. 1994. The high plains virus-a new threat to corn and wheat production in the west. Pages 156-164 in: Proc. 49th Annu. Corn and Sorghum Ind. Res. Conf., Chicago. American Seed Trade Association, Washington, DC.

10. Jensen, S. G., and Hall, J. S. 1995. Molecular characterization of a viral pathogen infecting maize and wheat in the high plains. Phytopathology 85:1211.

11. Jensen, S. G., and Lane, L. C. 1994. A new viral disease of corn and wheat in the high plains. Phytopathology 84:1158.

12. Jensen, S. G., Lane, L. C., and Seifers, D. L. 1996. A new disease of maize and wheat in the high plains. Plant Dis. 80:1387-1390.

13. Kamei, T., Goto, T., and Matsui, C. 1969. Turnip mosaic virus multiplication in leaves infected with cauliflower mosaic virus. Phytopathology 59:1795-1797.

14. Kassanis, B. 1963. Interaction of viruses in plants. Adv. Virus Res. 10:219-255.

15. Laemmli, U. K. 1970. Cleavage of structural proteins during the assembly of the head of bacteriophage T-4. Nature 227:680-685.

16. Matthews, R. E. F. 1981. Factors influencing the course of infection and disease. Pages 427-453 in: Plant Virology, 2nd ed. Academic Press, New York.

17. Rush, C. M., and Michels, G. J. 1995. Studies of a new disease of corn of unknown etiology in the Texas panhandle. Phytopathology 85:1193.

18. Seifers, D. L., Harvey, T. L., Martin, T. J., and Jensen, S. G. 1997. Identification of the wheat curl mite as the vector of the High Plains virus of corn and wheat. Plant Dis. 81:11611166.

19. Slykhuis, J. T. 1955. Aceria tulipae Keifer (Acarina: Eriophyidae) in relation to the spread of wheat streak mosaic. Phytopathology 45:116-128.

20. Towbin, H., Staehelin, T., and Gordon, J. 1979. Electrophoretic transfer of proteins from polyacrylamide gels to nitrocellulose sheets: procedures and some applications. Proc. Acad. Sci. USA 76:4350-4354. 